\title{
The Helixes of Vittorio Bonadè Bottino: Symbolism, Geometry and Architectural Types
}

\author{
Marco Giorgio Bevilacqua
}

Published online: 19 March 2015

(C) Kim Williams Books, Turin 2015

\begin{abstract}
The works of Vittorio Bonadè Bottino, engineer, were deeply linked to the affirmation and development of the Italian FIAT car industry, for which he worked from 1919, when he began to collaborate in the realization of the Lingotto factory in Turin. His relationship with FIAT grew over time and led him to assume increasingly important assignments. Among these were the social architectures that he designed for the company during the 1930s. The most representative were the two hotel towers in Sestrière and the colonies of Marina di Massa in Tuscany and Sauze d'Oulx in Piedmont; here he tested and consolidated his innovative architectural type of the cylindrical tower, where the helix represents the geometric matrix and the compositional key of the whole structure.
\end{abstract}

Keywords Heliotherapeutic colony · Tower · Italy · Fascism ·

Vittorio Bonadè Bottino · FIAT car industries · Symbolism · Helix ·

Helical ramp · Geometry · Rationalist architecture · Futurism

\section{Introduction}

The geometry of the helix and of its natural reduction to the plan, the spiral, has always generated strong emotions in man. Equiangular or logarithmic spiral, spiral of Archimedes, cylindrical and conical helixes; helicoids mathematically describe a form that is among the most widespread in nature, from the structure of the Nautilus, the shape of certain plants and the horns of a sheep, up to the most recent discoveries of the DNA double-helix structure (Sala and Cappellato 2003, pp. 128-147).

M. G. Bevilacqua $(\bowtie)$

DESTeC, Dipartimento di Ingegneria dell'Energia, dei Sistemi, del Territorio e delle Costruzioni, Università di Pisa, Largo Lucio Lazzarino, 1, 56126 Pisa, Italy

e-mail: mg.bevilacqua@ing.unipi.it 
Architecture and art have been fascinated by spirals and helixes since ancient times. From the Ionic volute in the Classical age or the ancestral depictions of the Tower of Babel, to the staircase at the 'Belvedere' attributed to Donato Bramante, the twisted columns of Gian Lorenzo Bernini and the formal experiments of Francesco Borromini in the Baroque era, helixes and spirals have frequently been proposed as the geometric root of shapes that aimed to have strong expressive and evocative value (Conti 2010, pp. 93-102).

In the twentieth century, the helix strongly comes back in modern architecture, for its ability to introduce a sense of movement, direction and to suggest an intimate vitality of matter. There are many examples, among which certainly the helical promenade of the Guggenheim Museum in New York by Frank Lloyd Wright (1943) is one, to have fully realized what Bruno Zevi identifies as the sixth invariant of the modern language in architecture: "the temporalized space, lived, socially enjoyed, able to accommodate and enhance events" (Zevi 1973, p. 53; my trans.).

Talking about helixes in modern architecture, however, the contribution of Vittorio Bonadè Bottino, Italian engineer, is surely less known. From 1932 to 1937 he built for the FIAT car industry four emblematic tower buildings: the "La Torre" hotel in Sestrière, the "Edoardo Agnelli" summer colony in Marina di Massa, the "Duchi d'Aosta" hotel in Sestrière and the Fiat winter colony in Sauze d'Oulx. In these four towers, built within the social policies promoted by FIAT and the Fascist regime in those years, the geometry of the helix surprisingly becomes the matrix of the whole structure (Fig. 1).

This paper aims to find which key words could be used in the reading of these architectural examples, where the helix is the generative element of the architectural program and, moreover, a sort of brand of Bonadè Bottino's most important architectural designs. For this purpose, however, we have to confront Fascism in Italy, not only in architectural terms, but also-and perhaps principallyconsidering how these kinds of shapes were used in the apparatus of symbols of
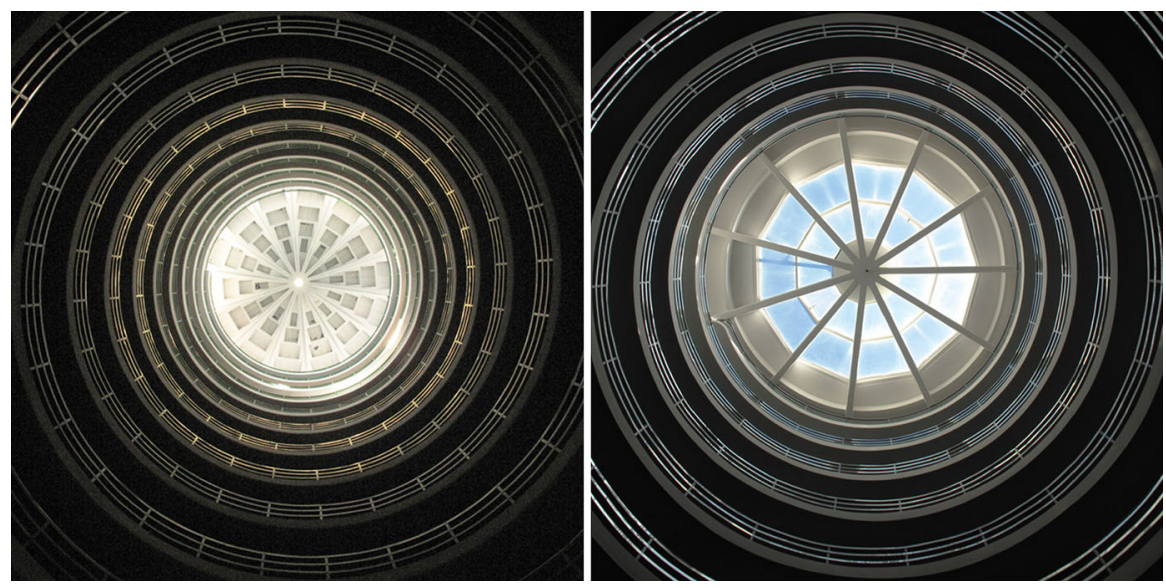

Fig. 1 The helixes of Vittorio Bonadè Bottino. On the left the helical ramp of the "Edoardo Agnelli" summer colony in Marina di Massa, Tuscany, on the right the helical ramp in the ex-Fiat winter colony in Sauze d'Oulx, Piedmont. Photos: author 
the regime. Furthermore, in order to understand the originality of these architectures, we must discuss on the one hand how these buildings were the product of the Fascist propaganda, and on the other hand how they were the expression of the Italian Rationalist culture, with its peculiarities and contradictions.

\section{Helixes: Futurist Symbolism and Fascist Propaganda}

In the period during which Bonadè Bottino realized his towers for the FIAT car industry in Italy, the suggestion of curved forms, and in particular helixes, had already been recovered and adopted by the Futurist culture, which often attributed to these the value of evoking a new era, based on scientific, industrial and technological development.

In the Futurism manifesto published on February 20, 1909 in 'Le Figaro', Filippo Tommaso Marinetti aimed to represent all the aspects of the urban environment, constantly evolving thanks to the human endeavour and to the new possibility of creating an artificial universe offered by technology and industry. The continuous progress of mechanical and transport engineering aroused great enthusiasm in the culture of the early 1900s. In addition to the car, train and tram, it was the plane that fired the dreams and passions of the Italian intellectuals (Lamberti 2003, p. 98).

In 1914, Antonio Sant'Elia published the Manifesto of Futurist Architecture. Here the city becomes the symbol of the dynamicity and modernity of the new society and culture. All of the Futurist urban designs are based on great infrastructure and modern transport, and in particular the plane. So, helixes, as other curve profiles, well symbolize the concept of what Sant'Elia defines as "Dinamismo Plastico" (Sant'Elia 1914)—Plastic Dynamism—the new dynamism with which art, architecture, cities and societies have to be reconceived: the helix refers to the turbine, the turbine to the engine, the engine to the new means of transport, such as the plane, to the industrial and technological development, to the new cultural and social dynamism.

The formal purity and the symbolic value of the helix thus reflected the Futurist idea for the new city, art and architecture, where "the beauty rises directly from the forms, the new materials, the imagination, the new perceptual, physical and sensorial sensitivity, which are generated by modern life and reflect themselves in the artistic creations" (Marinetti 1914, my trans.). Futurist aesthetics were therefore based on a new concept of beauty, which Marinetti called "mechanical and geometric splendour. This is essentially: the hygienic oblivion, the hope, the desire, the harnessed strength, the speed, the light, the will, the order, the discipline, the method, the sense of the big city" (Marinetti 1914, my trans.).

Fascism was able to get these early Futurist revolutionary impulses and retrieve its symbolism: the celebration of courage, the boldness, the glorification of war, the patriotism, the nationalist impulses, the exaltation of strength and virility, the trust in technological and industrial development. It's no coincidence that symbolism was introduced in Fascist architecture. Examples of this are found in the countless number of references to Mussolini, to the 'Fascio' that were scattered not only in the decorative apparatus, but also in the overall stereometry of the buildings, to such a 
high level that also Giuseppe Pagano-one of the most important Italian Rationalist architects-felt moved to condemn their abuse: "freely giving vent to all these resounding phrases, you have created an outer fictitious and rhetorical garment of modern architecture: movement of the masses, horizontal windows, flat roof, jagged terraces, bright plaster, unexpected novelties, shelters, curved walls, helical stairs and portholes and big Fascist emblems and flagpoles and immense portals and towers towers towers" (De Seta 2008, p. 32; my trans.).

From the Propylaea at the entrance of the Termini railway station (1939-1943) or the water reservoir of the colony "Rosa Maltoni" in Tirrenia (1925-1931) designed by Angiolo Mazzoni, the stair of the "Casa del Balilla" in Trastevere, Rome, by Luigi Moretti (1933) or that by Giuseppe Pagano in the new pavilion of the "Palazzo dell' arte" at the VI Triennale in Milan (1936), up to the most daring ramps of the Florentine stadium by Pier Luigi Nervi (1930-1932), just to list a few, the helix is one of the most used forms for symbolizing the national dynamism, the social evolution, the new Fascist era.

The Fascist era has a start date-1922 — and an end-1943: in these 20 years we see the birth, the strengthening and the decline not only of a regime, but also of an ideal deeply rooted in the society. In architecture, there was first a revolutionary impulse, partially of Futurist root, in which many architects saw the conditions for defining the basis of a new architecture and a new society; then, a certainly darker and totalitarian phase followed, which under the principle of the 'Romanitas' led the architecture towards maddeningly celebratory shores: "It was a violent impact, without ambiguity: the Regime, with the megalomaniac Roman farce, threw the mask" (De Seta 1988, p. 8; my trans.).

The most important years of this change were 1928 and 1936. 1928 is the year of the affirmation of Fascism and the redefinition of the political and administrative structure of the state. In that year the two most important magazines of architecture were published for the first time, 'La Casa Bella' and 'Domus', and the first Exhibition of Italian Rationalist Architecture was inaugurated in Rome. In 1936, with the conquest of Addis Ababa and the proclamation of the Italian Empire, the regime reached the height of its maximum prestige and consent. In the same year the sixth 'Triennale' was opened in Milan, which represented the cultural mediation of the two souls of Italian architecture: the academic, monumental one of Marcello Piacentini and the rationalist one of Giuseppe Pagano. It was possibly what Ciucci defines as "the idea of compromise between modern architecture, expression of the renewed social and economic condition promoted by the Fascist government, and the professional reality, which reduced 'modernity' to only the economic aspect, meant as down-market, typical of the construction industry, entrusting the main celebratory themes to the Art" (Ciucci 1989, p. 7; my trans.). In the discussions that took place between 1928 and 1936 on the role of the city and the meaning of architecture, Mussolini participated as the supreme judge. ${ }^{1}$ In this debate, words such as 'Roman', 'Mediterranean', 'celebration of heroes', 'exaltation of the race' echoed from both sides: rationalist and academic; with these words they intended to

\footnotetext{
${ }_{1}$ On the role of Benito Mussolini in architecture, see Nicoloso (2011).
} 
claim early primacy and at the same time to reconcile modernity and the architecture of the regime with a highly contradictory and unhistorical approach.

The most glaring example of this was the Gruppo 7-made by the architects Giuseppe Terragni, Luigi Figini, Gino Pollini, Carlo Enrico Rava, Guido Frette, Sebastiano Larco and Ubaldo Castagnoli-that had already in 1926 with a series of articles in the journal Rassegna Italiana presented the new standards of the Italian rationalist architecture, based on those of the European Modern Movement. ${ }^{2}$ In the declaration, the concepts of 'style', understood as rationality and response to the function of the building, and 'construction in series'- "from the constant use of rationality, from the perfect response of the building to the undertaken purposes, we must be certain that, just for selection, style will be the result"-were reconciled to the traditional values: "there is such a classic substrate and the spirit of tradition (not the forms which are very different things) is so deep in Italy that clearly and almost mechanically the new architecture will not fail to maintain a typicalItalian-imprint" (Gruppo 7 1926). In the manifesto they realized, therefore, the compromise between the incompatible concepts of tradition and modernity, between Le Corbusier's Esprit Nouveau and the classic style, which even in this contradiction led to important examples of modern architecture, such as the wellknown 'Casa del Fascio' in Como by Giuseppe Terragni.

Benedetto Gravagnuolo mentions this cultural ambivalence as well. In his essay 'Gli ossimori dell'urbanistica fascista', he compares in fact the evolution of architecture in the Fascist era to the even more complex ideological evolution of Fascism which, in a sort of winding path, "starting with a bold revolutionary fervour, settles on a more state conventional conservatism, up to the imperial mythomania, before plunging to the abominations of the war and the racial hatred" (Cresti et al. 2004, p. 33).

Giorgio Ciucci, borrowing the words of Palmiro Togliatti, analyses this ambivalence under the light of 'eclecticism': eclecticism both in the ideological and political principles, which ranged between nationalism and socialism, and in all the forms of cultural expression: "eclecticism as a cultural basis on which they justified different ideals for the sole purpose of political success" (Ciucci 1989, pp. 3-8).

In this difficult and complex context, there came the story of Vittorio Bonadè Bottino, deeply linked to the city of Turin and to the development of the FIAT car industry in Italy.

\section{Vittorio Bonadè Bottino and the FIAT Car Industry in Turin}

In the 1920s Turin was a virtual political, cultural and artistic laboratory. In the years immediately preceding the First World War, in Turin more than in other Italian cities, the basis of the national industrial development were already laid; in

\footnotetext{
2 The manifesto of the Gruppo 7 was published in different papers in the journal Rassegna Italiana from December 1926 to May 1927: "Architettura" December 1926, "Gli stranieri" February 1927, "Impreparazione, incomprensione, pregiudizi" March 1927, "Una nuova epoca arcaica” May 1927. For more information about Rationalist Architecture refer to Danesi and Patetta (1988).
} 

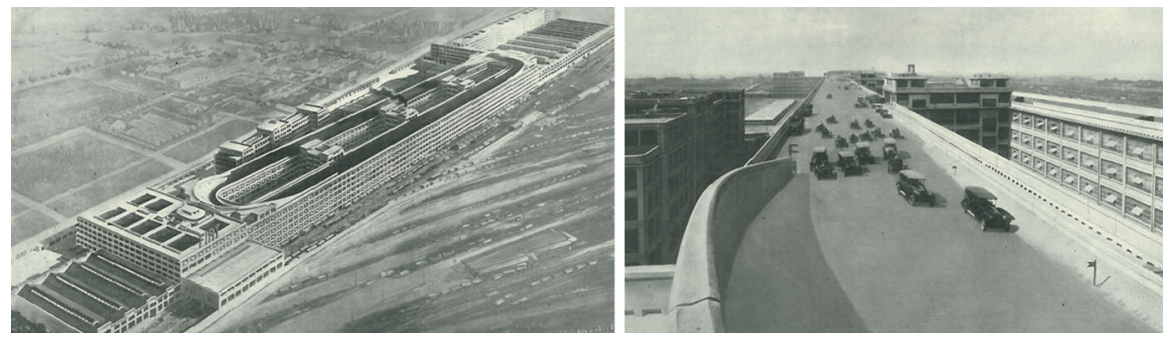

Fig. 2 The FIAT Lingotto factory. On the left aerial view of the factory in a historical photo, on the right view of the test track on the roof. Images: Tofanelli (1932), pp. 549-550. Courtesy of the General Archives of the University of Pisa

the first post-war period also, in Turin, the conflicts between workers' organizations and entrepreneurs reached harsher levels, defining also the basis for a very advanced political and cultural elaboration. It was in the clash between these two components-workers and entrepreneurs-that the position of some bourgeois intellectuals matured, which defined a political and cultural project in the context of an overall development of the social parts. In this atmosphere, Turin became a point of reference for many writers, artists and architects. They discussed the need to have a profound effect on society, they interpreted the changes underway promoting the cultural European avant-garde. This group of intellectuals and artists-such as Lionello Venturi, Edoardo Persico, Felice Casorati, Giuseppe Pagano and Alberto Sartoris-lived together with the artists of Turin's eclectic tradition, such as the painter Giacomo Grasso, the sculptor Edoardo Rubino and the architect Giovanni Chevalley (Ciucci 1989, pp. 37-56).

The coexistence of these two strains - progressive avant-garde and traditionwas reflected in the architectural and urban-scale interventions, aimed at giving a new image to the city: the eclectic style of Giovanni Chevalley's Cassa di Risparmio (1929-1931) matched with the rationalism of the project for via Roma made by the M.I.A.R. group in $1931,{ }^{3}$ just to mention a few of the most significant ones.

In this Turin of avant-garde culture, of socialist ideology and of enlightened, liberal and progressive industrialists, there was the personal story of Bonadè Bottino, who, even though he did not actively take part to the cultural debate of those years, would became one of the protagonists of the new architectural scene. ${ }^{4}$ Born in Turin in 1889 in a bourgeois family, he carried out his studies until 1914 when he earned a degree in engineering at the Politecnico. After a brief period in Reggio Calabria as a provisional member of the Civil Corps of Engineers, in 1919 he entered the studio of Francesco Cartesegna, an engineer who was at the time engaged in the direction of the construction of the new FIAT car industry headquarters at Lingotto, designed by Giacomo Mattè Trucco (Figs. 2, 3).

\footnotetext{
${ }^{3}$ The M.I.A.R. group (Movimento Italiano di Architettura Razionalista) for the project of via Roma in Turin was composed of Giuseppe Pagano-Pogatschnig, Umberto Cuzzi, Gino Levi-Montalcini, Ottorino Aloisio, and Ettore Sott-Sass.

${ }^{4}$ For the complete biography of Vittorio Bonadè Bottino see Banfo $(1997,2003)$ and Bonadé Bottino (2001).
} 
Fig. 3 The helical ramp in the Lingotto factory. Photo: Kim Williams

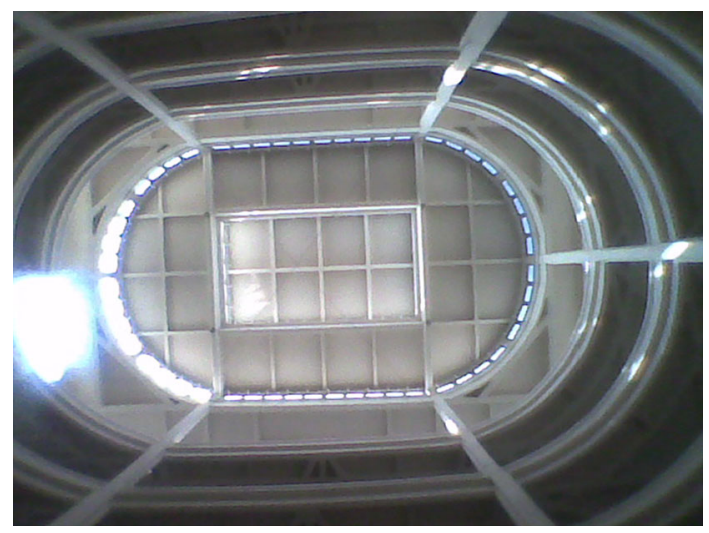

The Lingotto factory answered the need for the development of the productive potential of FIAT, which during the First World War had increased the workforce from 4000 to 40,000 . With a covered surface of $1,26,000$ square metres, and a volume of 1,694,000 cubic metres, the structure was designed to contain all the phases of car construction along a vertical distribution. The productive cycle, starting from the ground floor, ended at the roof level, where a test track was placed-24 metres wide with linear stretches of 433 metres in length, connected by inclined parabolic curves. Two helical ramps concluded the distributional scheme, to lower cars from the roof after the test to be transported to the nearby train station. The frequent visits to the site and the skill in working earned Bonadè Bottino the task of designing the test track. For Lingotto he was also engaged in the calculation of the reinforced concrete and of the two ramps, which represented the first prototype of a structural design that he would later propose in the designs of towers. The inauguration of Lingotto occurred in 1923 in the presence of the King, although the helical ramps were not completed until 3 years later.

In the same years, with Cartesegna, Bonadè Bottino worked at the projects for Moncenisio's hydroelectric plant, the rubber-processing plant in Bergougnan, and the Turin-Milan-Genoa road. With the advent of the regime, he joined the Fascist party, perhaps out of opportunism and lack of solid political values, as he confessed several years later in his memoirs (Bonadè Bottino 2001, p. 234). From 1925 to 1927 his career took off. In 1927 the relationship with Fiat, and in particular with Giovanni Agnelli, became an exclusive one. It was for FIAT that he designed the most significant works, from the industrial ones-the glass industry in Porto Marghera near Venice (1925), the new Fiat Mirafiori in Turin (1937), the FIAT plant in Florence (1939) — to those that FIAT promoted in the social and welfare field: the 'Tina Nasi Agnelli' sanatorium in Pra' Catinat, Turin (1930), the FIAT colonies in Marina di Massa (1933) and Sauze d'Oulx (1936), the houses for workers in 'via Carlo del Prete' in Turin (1939) and the village for workers in Villar Perosa at Pinerolo (1940-1941).

These years of intense activity defined also the maturation of Bonadè Bottino as an architect. From his early eclectic works, like the Cine Palazzo in Turin (1926), he 
consolidated a rationalist vision of the architecture, closer to that functionalist spirit of the industrial architecture in which he became a protagonist. After the war, he continued his hard work and collaboration with FIAT, where he held leadership roles in the Construction and Equipment Division. ${ }^{5}$ He died in Turin in 1979.

\section{FIAT and the Fascist Social Architecture}

From 1925, the Fascist government promoted many actions in the social sphere. With these social initiatives the regime on the one hand looked for popular support, and on the other, especially with those aimed at children, it conveyed the principles of Fascism and implemented a program of Fascistization from an early age. To the interventions promoted by the regime there were also those undertaken by industries: a kind of alliance and connivance with which the ruling class exerted a fine-grained control over the working class.

They recovered and implemented for this purpose a tradition that had its roots in the previous century, in the phenomenon that historians call "industrial paternalism" (Ciuffetti 2004). In the nineteenth century, in fact, paternalism was an expression of the entrepreneurial mindset and aimed at the annulment of social tensions, in order to manage the working class and ensure industrial production. The promotion of social initiatives was aimed at promoting the illusion of the factory as a big family and the entrepreneur as a father, ever attentive to the needs of his children-workers.

In the years between 1900 and 1930 in Italy, as in other European countries, there was a major development of industry and infrastructure. Turin and Milan became centres of excellence in the fields of mechanical and steel industry, which were the leading sectors of the national economy. With the advent of Fascism, entrepreneurs tried to develop a special relationship with Mussolini, who favoured their policies of development, in exchange for reasonable financial and political support. The ultimate goal was that of maintaining the status quo, cancelling any social conflict and, consequently, any socialist and anarchist leanings among the popular masses. ${ }^{6}$

FIAT was certainly one of the companies that invested heavily in the creation and organization of social services. The interventions made by FIAT from the 1920s, in fact, were not limited to the opening of after-work centres in Turin: FIAT realized entire quarters and villages for workers, and seaside and mountain colonies. The set of welfare and recreational facilities, together with all the initiatives in the area of

\footnotetext{
5 For the complete list of the works of Vittorio Bonadè Bottino see Vivaldi (2006-2007, pp. 126-130).

${ }^{6}$ For this purpose, the Fascist government founded various organizations, including the 'Opera Nazionale Dopolavoro' (OND) in 1925 and the 'Opera Nazionale Balilla' (ONB) in 1926. With the first, the government realized, both with public and industrial assets, several recreation centres for workers and their families, where caring about "the moral and physical health of the people" was demonstrated through sports, hiking, tourism, art education, popular culture, social and health care, and professional education. The second, the ONB, was made for the assistance and physical and moral education of youth, in order to establish a widespread indoctrination of young people in the ideology of Fascism, in a sort of a paramilitary organization. A system was created that instilled in people the sense that the "achieved benefits could not be apparently separated from the forced loss of freedom rights, already acquired by workers' organizations in the past" (Cresti 1986, pp. 87).
} 
social security, aimed to instil in the FIAT employees the awareness of belonging to a privileged class. The workers and their families, in fact, could take advantage of the services offered in the summer and winter colonies, they could participate in sports and cultural activities organized by the company, have access to affordable rented homes, and enjoy significant benefits in the field of health insurance.

In this highly centralized and controlled social context, there were the four towers designed for FIAT by Vittorio Bonadè Bottino, standing out for their innovation: the two towers at Sestrière, the tower "Edoardo Agnelli" in Marina di Massa, and the winter colony in Sauze d'Oulx.

\section{The FIAT Towers}

The "La Torre" hotel at Sestrière was the first project in which Bonadè Bottino concretely experimented with the helical shape as the main compositional matrix (Fig. 4).

The building was part of a larger project aimed at the creation of a mass tourist centre for ski sports that FIAT promoted starting in 1930. The project included hotels of different categories, business accommodation, ski lifts and infrastructural networks. A great operation that led to the radical transformation of a site that, until that moment, had been untouched. The choice of the area, on the hill of Sestrière

Fig. 4 "La Torre" hotel in Sestrière. External view. Photo: author

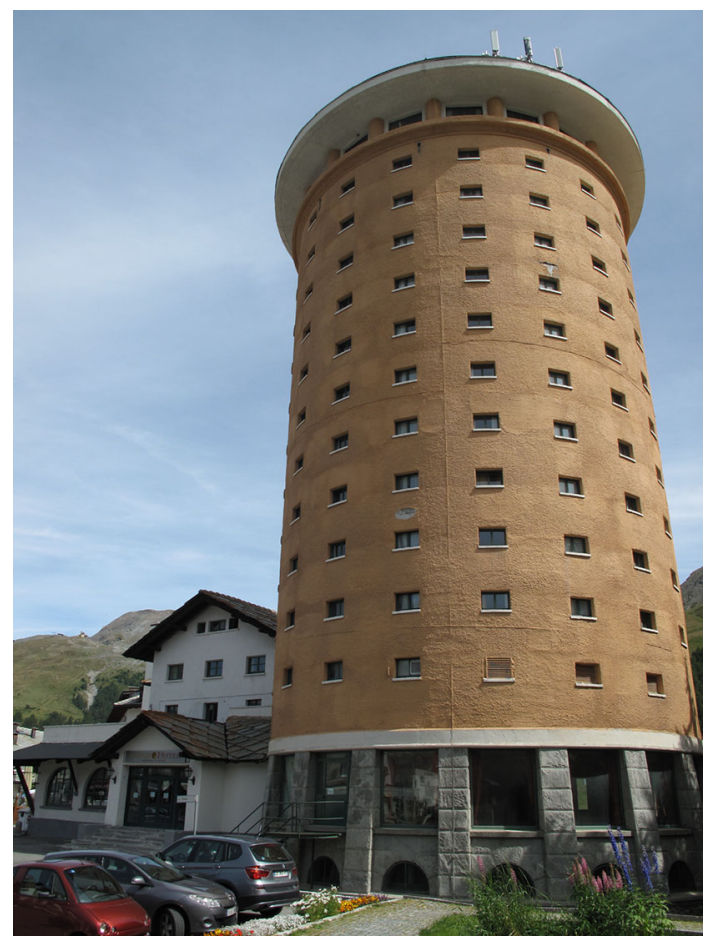


between Val Chisone and the Valley of Susa, was strongly supported by the Agnelli family_and in particular by Giovanni and his son Edoardo-which saw in the proximity to Turin the possibility to develop mass sports, if only for brief stays during weekends. At Sestrière, from 1930 to 1932, they realized the "La Torre" hotel, designed by Bonadè Bottino for a popular clientele, and the "Principi di Piemonte" hotel, designed by Giovanni Chevalley and Mario Passanti for the leisure-class. In these two structures, formally opposite, the differences of class were highlighted by the architectural language: essential, modern and protorationalist in the first; elegant, traditional and eclectic in the second.

The project report for the "La Torre" hotel, written by Bonadè Bottino, was integrally published in the journal 'L'Architettura Italiana' in March 1933. The building is described with an abundance of both formal and technical engineering information. The project started from the necessity to realize a dormitory building for no fewer than 150 skiers. The study of the building was defined then on the basis of a precise functional program, aimed at the reduction of the capital investments in order to assure a final cheap service (10 lire a night). Bonadè Bottino started defining the minimum space for the basic cell, the single cabin (Fig. 5): "the berth or compartment or the cab [...] and the services that each element would have had" (Bonadé Bottino 1933, p. 45; my trans.).

He proceeded by aggregating the cells in the best configuration: 16 cabins with common restroom. The need to limit the costs arising from the excavation in rock finally determined the choice to arrange the distribution system in a vertical structure, limiting as much as possible the footprint of the building and, consequently, the foundation's extension. Other elements occurred in the definition of the building program: the problem of good ventilation in relation to the small volume of the cabin and that inherent to the reduction of exterior exposed surfaces. The first result was a tower where the cabins were distributed on each floor around a

Fig. 5 "La Torre" hotel at Sestrière. Plan of a couple of single cabins. Drawing: author

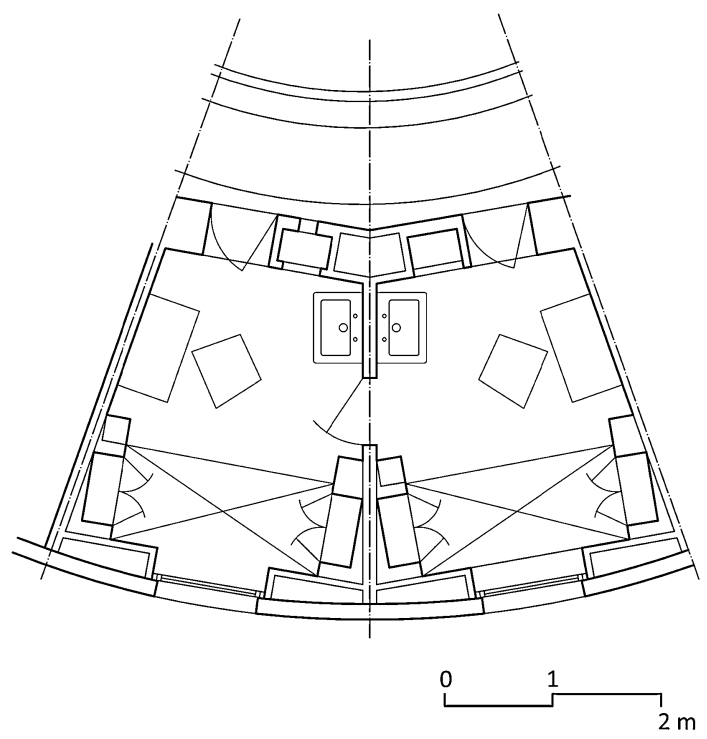




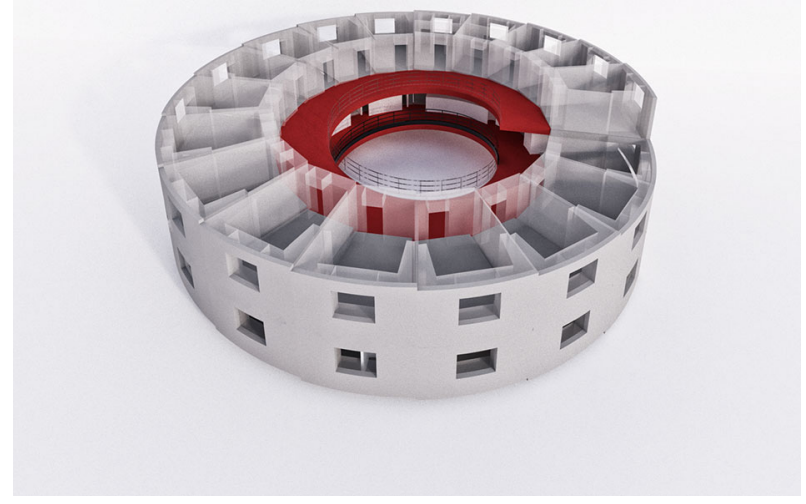

Fig. 6 "La Torre" hotel at Sestrière. 3D scheme of the aggregation of the single cabins along the helical ramp. Image: Andrea Crudeli and Giulio Fazio

central gallery. The idea of a continuous helical ramp, which defined the architectural code of this innovative type of building, was due to Giovanni Agnelli (Fig. 6): "Sketched a draft project of the tower, with a helical ramp for the access to each floor, remembering the helical ramps at Lingotto, the senator-Giovanni Agnelli-proposed to extend the helical surface to the entire width of the ring and to place the cabins on staggered levels, equal to a portion of the helix pitch; in this way the tower at Sestrière was born" (Bonadé Bottino 1933, p. 45; my trans.).

The building appears outside as a highly compact cylindrical tower, 38.10 metres high and with a diameter of 18 metres (Fig. 7). There are still eclectic echoes in the ashlar treatment of the sloped base and in the decoration of the upper crowning. The structure, in reinforced concrete, is made by two concentric rings of pillars and ribbed slab floors. In the basement are the toilets and the common showers, the infirmary and the ski-storage. The ground floor is a 220 square metre wide single circular room, used as a hall-restaurant. From the first floor, and connected to the ground via a stairwell, the helical ramp starts, with 160 cabins distributed along its 10 coils. The helix pitch-and consequently the storey-height measured in each cabin-is 2.30 metres. Each coil is divided into 18 sectors where there are 16 cabins, one restroom and the lift shaft (Fig. 8). In the inner well-10.50 metres in diameter-the reinforced concrete helical ramp is cantilevered for a width of 1.25 metres. The building is completed by the round belvedere on the last floor. The central well is closed by a glass and concrete slab ribbed floor. In the morning, the light filtering through the glass plates is sufficient to illuminate the barrel of the tower; during the night, a single lamp placed at the centre of the slab provides lighting. ${ }^{7}$

\footnotetext{
7 Recent works for adapting the building to the fire prevention regulations have irremediably twisted the original arrangement of the helical ramp. A new concrete staircase, in fact, has been built inside the barrel of the tower. The same fate has befallen the second tower at Sestrière, the "Duchi d'Aosta" hotel.
} 


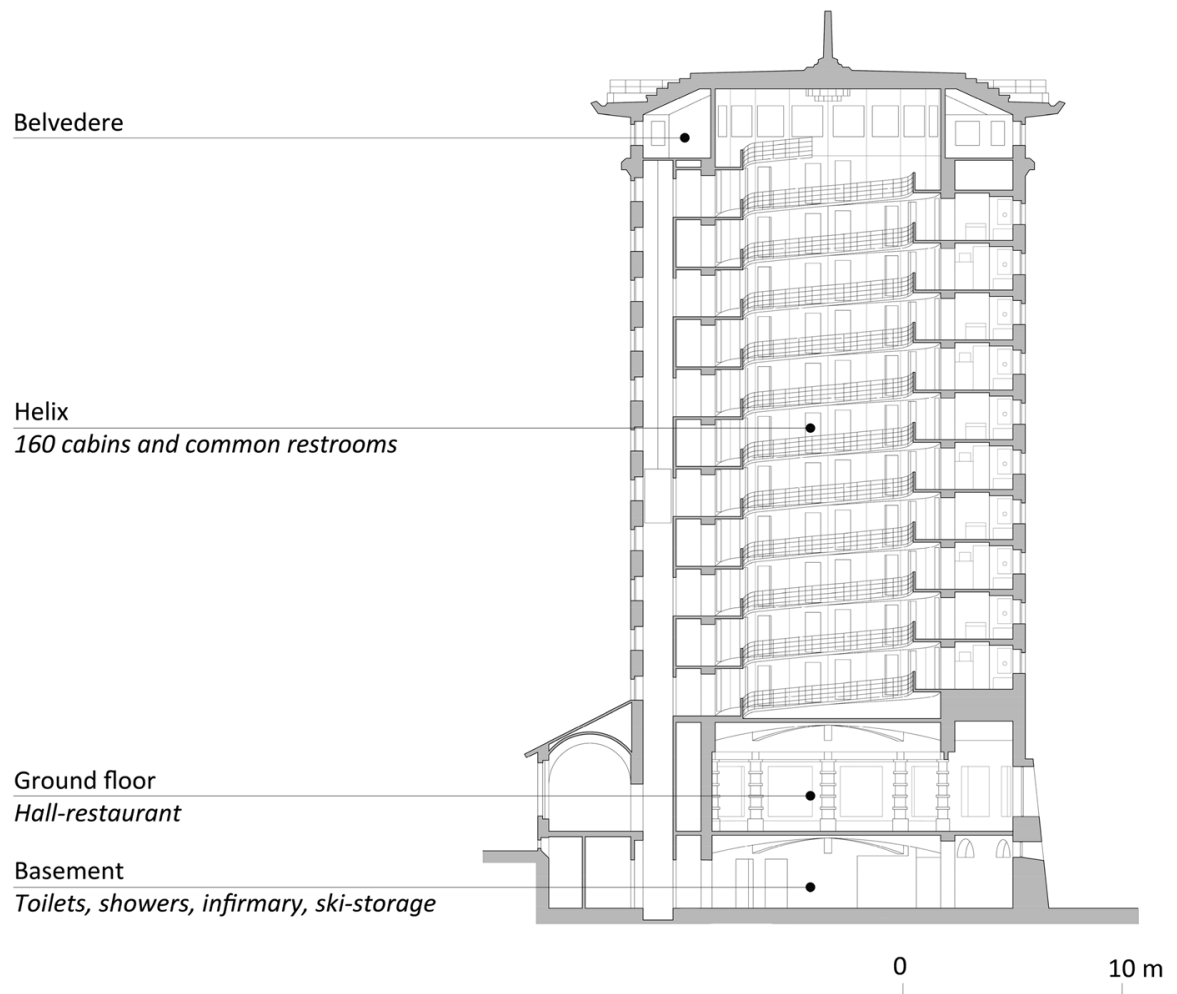

Fig. 7 "La Torre" hotel in Sestrière. Vertical Section. Drawing: author

The construction began in May of 1932 and was completed in only 6 and a half months. Soon after, construction began on the second tower designed by Bonadè Bottino: the summer colony in Marina di Massa on the Tuscan coast (Fig. 9).

The building was part of the Fascist plan of action aimed at the realization of social activities for the care and training of the Italian youth. The great number of summer and winter colonies, realized from the late 1920s, played in fact a central role not only in the fight against childhood diseases, such as tuberculosis, but also in the politics of demographic development and de-urbanization, in addition to the aforementioned purposes of indoctrination of the new generations to the Fascist ideology (Cutini and Pierini 1993, pp. 9-11).

The establishment of colonies for heliotherapy actually started in the midnineteenth century. Alongside the first British studies on heliotherapy for childhood tuberculosis, Italy made a significant contribution to the definition of thalassotherapy treatments. In the first post-war period in Italy there were already several hundred structures for thalassotherapy, including prophylactic nurseries, holiday camps, open-air schools, heliotherapeutic centres, seaside and mountain colonies, daytime, temporary and permanent colonies, and sea hospices. The Fascist government adopted health protocols to combat a still worrying phenomenon of 


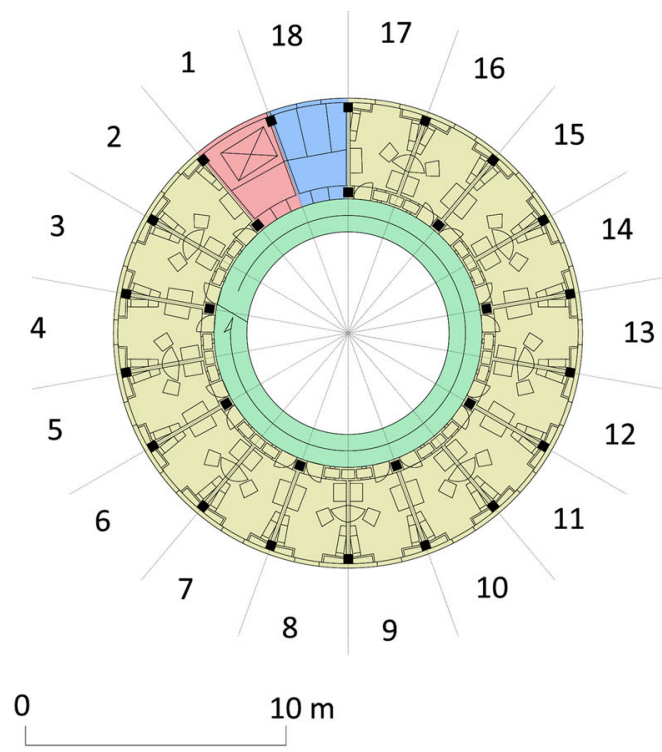

160 single cabins |16 a coil

¿ Helical ramp

îं Toilets | 1 a coil

故 Elevator

Data:

Tower

height $38.10 \mathrm{~m}$

external diameter $18.00 \mathrm{~m}$

volume $9680.00 \mathrm{mc}$

Helix

clockwise

10 coils +1 coil to the belvedere

coil height: $2.57 \mathrm{~m}$

internal diameter: $10.50 \mathrm{~m}$

ramp width: $1.25 \mathrm{~m}$

ramp slope: $8.60 \%$

ramp length: $300.00 \mathrm{~m}$

Fig. 8 "La Torre" hotel in Sestrière. Plan scheme of the tower. Drawing: author

Fig. 9 "Edoardo Agnelli"

Summer Colony in Marina di Massa. External view.

Photo: author

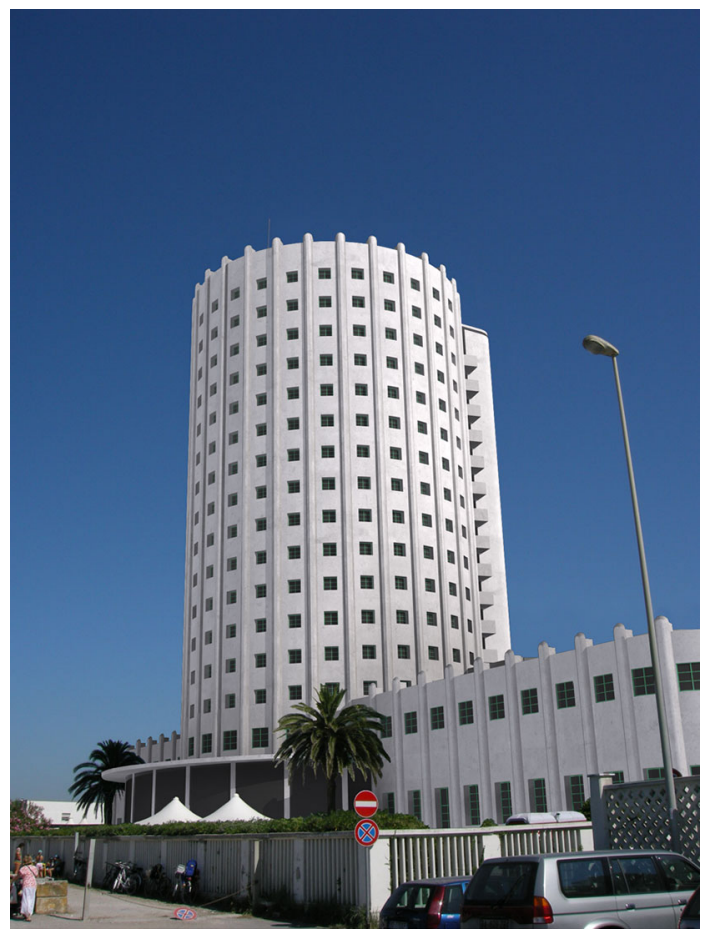




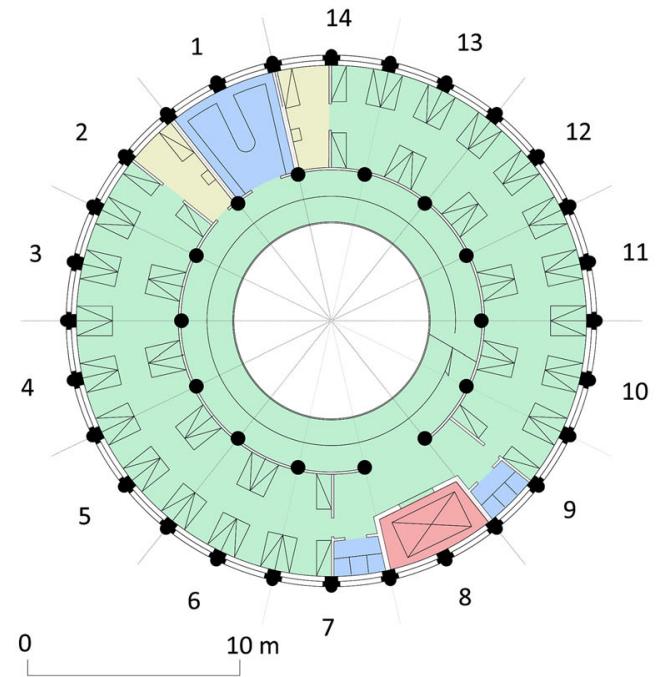

Bedroom for nurses 2 a coil

- Helical ramp | dormitory $\mid 60$ beds a coil

iif Toilets-washbasins

艄 Elevator

DATA

Tower

height $52.00 \mathrm{~m}$

external diameter $25.00 \mathrm{~m}$

volume $20.000 \mathrm{mc}$ / $35.000 \mathrm{mc}$ with base

helix

counter-clockwise

number of coils 13,5

coil height $2.60 \mathrm{~m}$

internal diameter $9,00 \mathrm{~m}$

ramp width $8.00 \mathrm{~m}$

ramp slope $5.0 \%$

ramp length $420.00 \mathrm{~m}$

Fig. 10 "Edoardo Agnelli" summer colony in Marina di Massa, Tuscany. Plan scheme of the tower; original configuration. Drawing: author

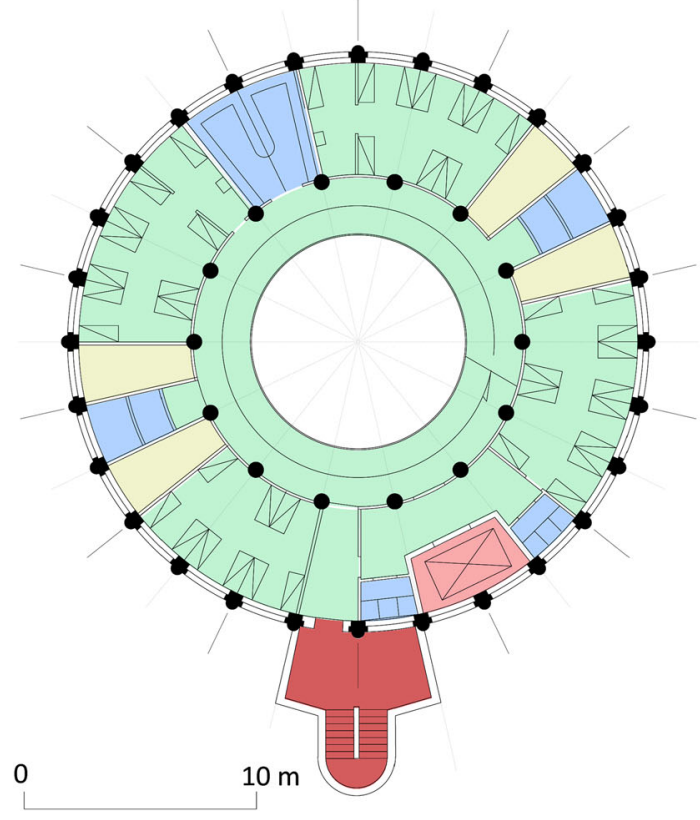

Bedroom for nurses | 2 a coil

¿ Helical ramp-dormitories

ii Toilets-washbasins

蛧 Elevator

Fire staircase

Fig. 11 "Edoardo Agnelli" summer colony in Marina di Massa, Tuscany. Plan scheme of the tower; present configuration. Drawing: author 


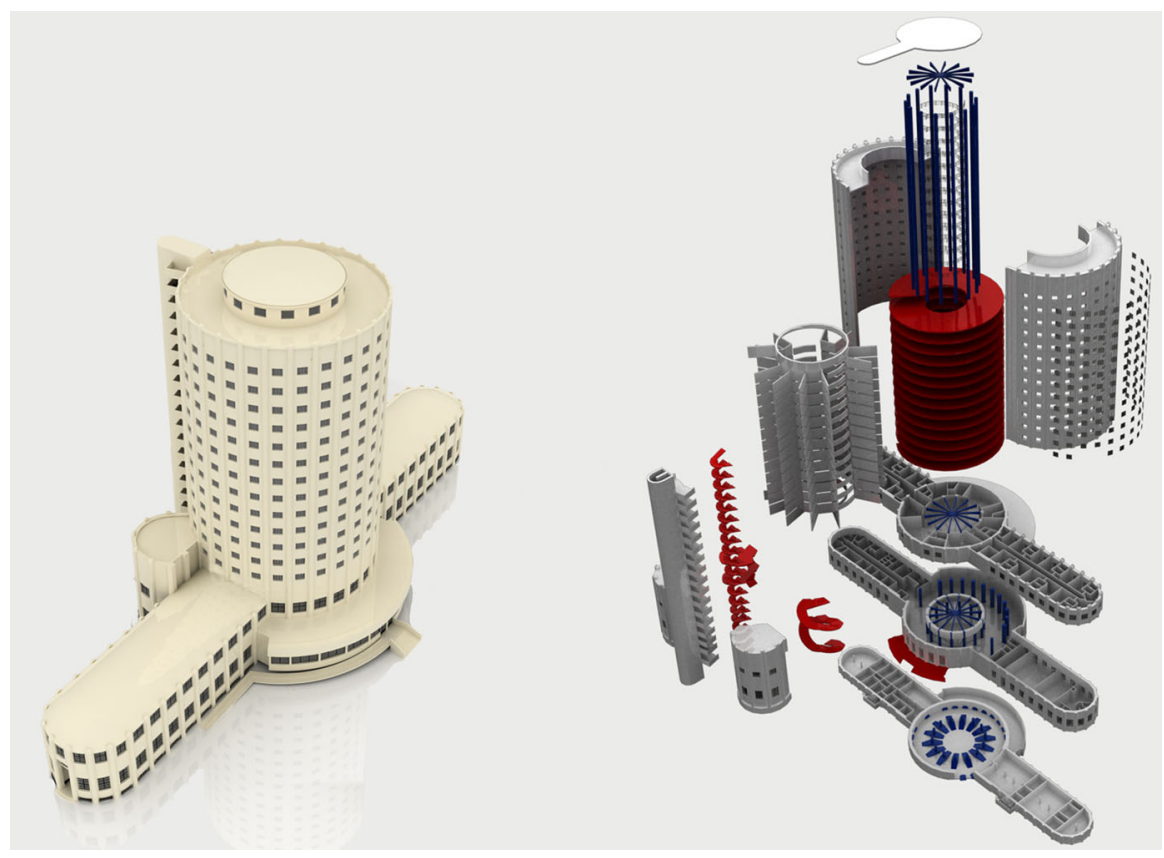

Fig. 12 "Edoardo Agnelli" summer colony in Marina di Massa, Tuscany. 3D model and exploded view; present configuration. Drawing: A. Fiorenti, D. Mariani, S. Gianfaldoni, M. Cestari, A. Donatucci, M. Tirico, and G. Pisanu

infant mortality, even if betraying the mid-nineteenth-century feelings of solidarity and philanthropy for the mere pursuit of athletic power and superiority of the Italian race. ${ }^{8}$ Tuscany was probably the region most interested in the development of this program: from 1918 to 1945 there were 42 heliotherapeutic structures built on its coast, in addition to the dozen built just before the First World War (Cutini and Pierini 1993, p. 97).

As we have said, many Italian industries participated in this policy; among these, there was primarily FIAT which built various structures including, as mentioned, those designed by Vittorio Bonadè Bottino.

In the colony "Edoardo Agnelli" in Marina di Massa-also known as "Torre Balilla" and then "Torre FIAT"-Bonadè Bottino proposed again the architectural and functional scheme of the hotel in Sestrière, emphasizing, however, the value of the helix which was extended throughout the tower. He then designed - and built in only 100 days (Canova 1933) - a 420 metre long single dormitory which wrapped in coils directly overlooking the sea.

\footnotetext{
${ }^{8}$ The Regime entrusted the management and organization of the colonies to the "Opera Nazionale Maternità e Infanzia" (ONMI), established in 1925, and to the "Opera Nazionale Balilla" (ONB), founded in 1926. The OMNI, originally created for the protection of pregnant women and children under 5 years old, was responsible for the management of the permanent colonies as part of its prophylaxis activities against childhood tuberculosis and scrofula, while the ONB was in charge of the temporary colonies for poor children and for the children of ex-combatants and Italians living abroad.
} 

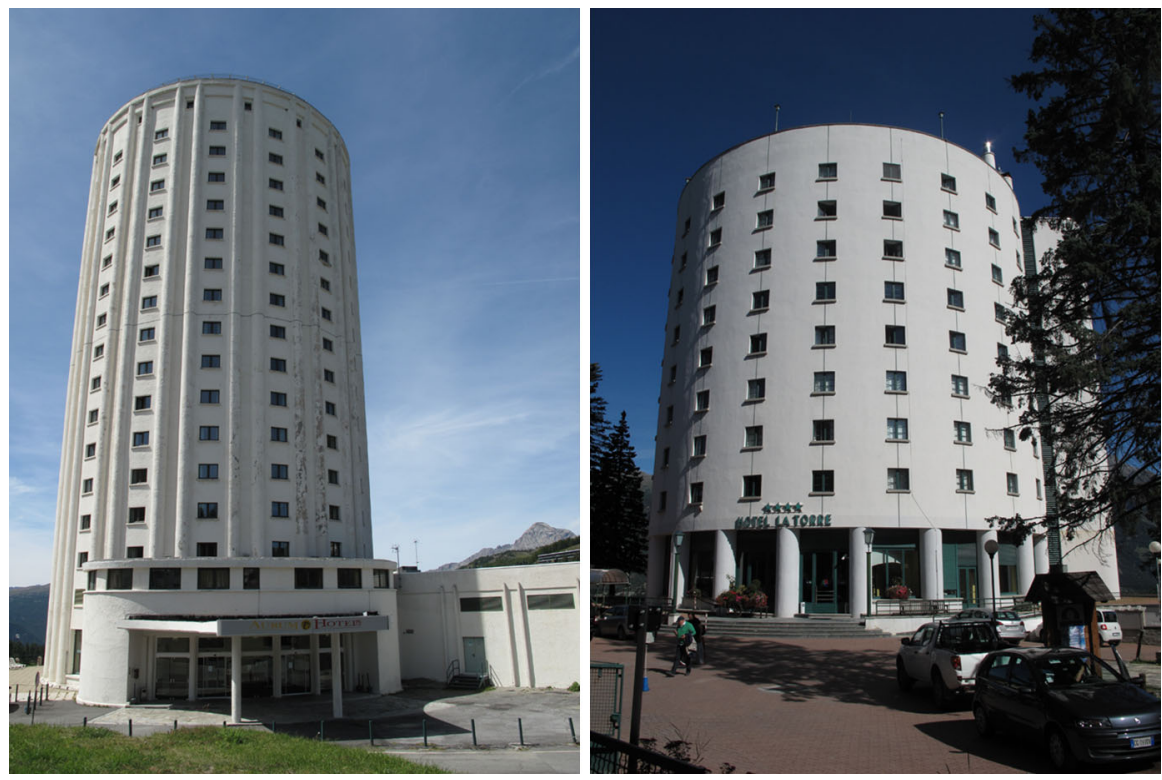

Fig. 13 External views of the "Duchi d'Aosta" Hotel (on the left) and the ex FIAT winter colony in Sauze d'Oulx (on the right). Photos: author

The project was based on the necessity to obtain the prescribed volume for each bed-25 cubic metres - using the tower's large central well, covered as in the case of Sestrière, by a glass and concrete slab ribbed floor. In the helical ramp were placed 25 dormitories of 30 beds each, 30 rooms for nuns and minders, for a total of 780 beds. All the dormitories were open to the inner shaft and separated from the central ramp by a 1-m high wall. Beds were placed radially in two orders; in order to remedy the problem of the sloping floor, beds were made with legs of different heights. In each coil there were two dormitories (30 beds, the room for the nun and the minder, one group of toilets and one of washbasins) and the shaft of the elevator that could contain an entire team (30 children, nun and minder) (Fig. 10). The last coil of the helix was half-occupied by a 100 cubic metre water tank. ${ }^{9}$

The tower starts from the second floor; in the longitudinal volume at the base there were common functions, such as storage, the thermal and electrical plant and a dormitory for the male staff (underground floor) at the underground level; common services (restaurant, kitchen, nursery, administration, showers and toilets) at the ground floor and a big hall at the first floor (Fig. 12).

These two projects, where Bonadè Bottino defined the characteristics of this new architectural type, were followed closely by other two buildings: the "Duchi d'Aosta" Hotel in 1936, also at Sestrière, where he reused the distributive scheme of

\footnotetext{
9 The building preserves its original layout quite well (Fig. 11). The long dormitories have been divided into smaller ones; new toilets have been built also along the helical ramp. Outside, a new external fire staircase has partially damaged the monolithic perception of the tower from the land side; this solution is surely more advisable than the one used at Sestrière, because it does not alter the integrity of the helical ramp.
} 
Fig. 14 Symbolisms in the shape of the "Edoardo Agnelli" colony, from an aerial view: a plane that has nose-dived on the beach; a gear of an engine.

Drawing: author
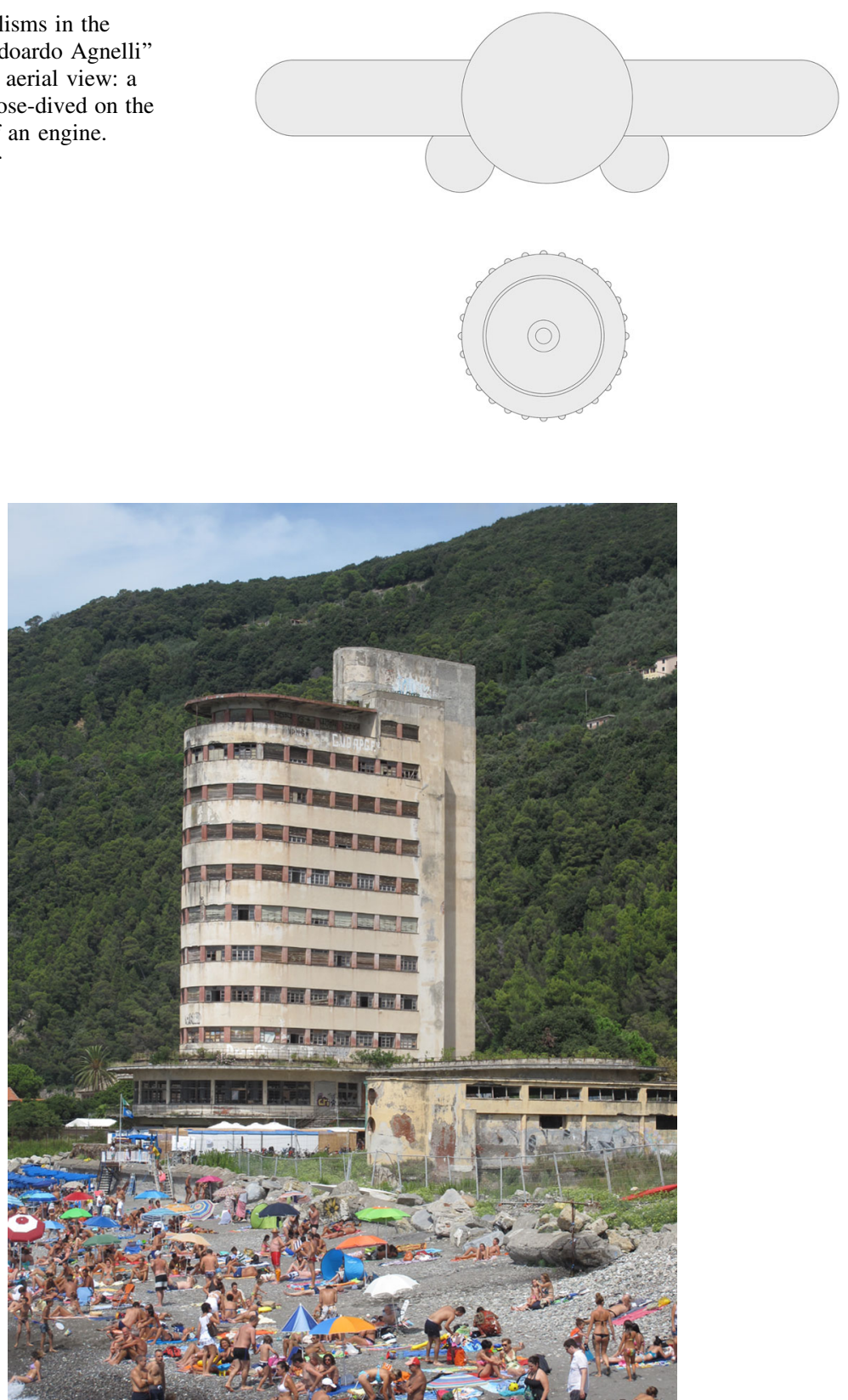

Fig. 15 the "Federazione dei Fasci di combattimento" colony in Chiavari (Camillo Nardi Greco 1935-1936). Photo: courtesy of Roberto Dell'Agnello

the "La Torre" hostel with a mature rationalist language, and the mountain colony at Sauze d'Oulx in 1937, where the type of Marina di Massa was repeated with light variations in the base structure (Fig. 13). 
The service offered by the "Duchi d'Aosta" Hotel was of intermediate level between the popular in "La Torre" and the luxury of "Principi di Piemonte". In comparison with the first tower, there was a substantial expansion of the service spaces and the addition of a basic structure for common activities and accommodations. It also offered different room typologies — single and double cabins-with or without private bathroom. Outside, as in Marina di Massa, he represented the semi-cylindrical pilasters, but in a new twin version.

The winter colony in Sauze d'Oulx may be considered as a reduced copy of the "Edoardo Agnelli": only $35 \mathrm{~m}$ high, $30 \mathrm{~m}$ across, and with a capacity for only 496 guests, distributed also in this case along a single helical dormitory. The functional program was similar, although reduced: 15 dorm rooms in total, each with 32 beds, 2 dormitories a coil, equipped with toilets and common rooms for minders, and the elevator shaft. Externally, the tower is a brick monolith, pierced by the windows of the dormitories, which follow the helix-ascending path. The monolithic aspect of the part where the helix is contrasts with the open base made by white columns and large windows. ${ }^{10}$

\section{Conclusion}

The Futurist dynamism of the helix in all these buildings is strengthened by the verticality of the tower, by the pursuit of beauty in bold structures, by the relationship that these create between earth and sky, in the conquest of the third dimension as a new frontier for the city.

This aspect is certainly more present in the colony of Marina di Massa than in the other ones. On the Tuscan coast, even in its stylistic simplicity, we find many symbolic references. Symbols of Futurist roots are in the conformation of the entire volume of the building, which looks like a plane that has nose-dived on the beach. This building, as in the case of other fascist architectures, has been thought to be seen from an airplane. The plan of the tower refers also to the shape of a gear and then to the industry and the technological development of Fascist Italy (Fig. 14).

Other clear references to the Fascist symbolic apparatus are in the external treatment of the tower with semi-cylindrical pilasters, which refers to the "Fascio Littorio" and, more generally, to a classic column, both symbols of the 'Romanitas'.

Beyond the symbolism in the formal choices that led the towers to evoke the scenarios of a society in transformation, the most important fact is that the FIAT towers were the product of a highly technical approach to architecture. Vittorio Bonadè Bottino managed the project of the towers with the same program with which he realized industrial plants and infrastructures: functionalism, efficiency, cost limitation, maximization of productivity. All these elements well represent the Rationalist standard of beauty, based, as we said, on rationality, response to function and 'construction in series'.

\footnotetext{
10 The building has been converted into a luxury hotel. The original brick color of the tower has been replaced by white. A new fire staircase, as in Marina di Massa, has been built outside for security reasons. Inside, the long dormitories have been divided into rooms of different typologies.
} 
Another important fact is that cylindrical towers and helical ramps are the main elements of a new innovative type of building. In the typological series with which it is possible to classify the heliotherapeutic colonies in Italy-the village, the block, the open-plan-the two structures designed by Bonadè Boottino in Marina di Massa and Sauze d'Oulx introduced a new typology for colonies: the tower. This didn't see other applications, except for the simplified case of the "Federazione dei Fasci di combattimento" colony in Chiavari designed by Camillo Nardi Greco in 1935-1936, where dormitories were placed in eight horizontal floors overlooking the sea, connected by an external volume with toilets, staircase and elevator (Fig. 15).

On the basis of the above considerations, it is certain that these structures do not have a secondary role in the context of modern architecture. A full 10 years before Frank Lloyd Wright's design for the Guggenheim Museum in New York, the towers concretize the idea of dynamic exaltation in architecture; the helix is not limited to merely defining some constituent elements, rather, it becomes the generator of the whole architectural space.

Architecture as path, temporality of space, technological innovation, equilibrium between form, function and structure, define only some of the invariants that allow us to fully enter the towers by Bonadè Bottino, among the more meaningful examples of modern architecture in Europe.

Acknowledgments 3D models of the "Edoardo Agnelli" Summer colony are by Alessandro Fiorentini, Davide Mariani, Silvia Gianfaldoni, Alessandro Donatucci, Maurizio Cestari, Michele Tirico, Gian Michele Pisanu, students of the Laboratory for Cad Application, taught by the author in 2009 in the Master Degree Course in Building Engineering and Architecture of the University of Pisa. Heartfelt thanks go to Andrea Crudeli and Giulio Fazio, students of the same degree course, for the 3D images of the "La Torre" Hotel in Sestrière. Thanks go also to Kim Williams for the photo of the Lingotto and to Roberto Dell'Agnello for the image of the colony in Chiavari.

\section{References}

Banfo, C. 1997. Dal Lingotto a Mirafiori. Bonadé Bottino e l'Organizzazione del Servizio Costruzioni della Fiat. Le Culture della Tecnica, 1: 85-104.

Banfo C. 2003. Bonadè Bottino, Vittorio (ad vocem). In: Dizionario dell'Architettura del XX Secolo, Vol. I, ed. Carlo Olmo. Rome: Istituto della Enciclopedia Italiana Treccani.

Bonadé Bottino, V. 1933. Albergo Turistico "La Torre di Sestrières". L'Architettura Italiana, fasc. 3, anno XXVIII (March-XI): 45-56.

Bonadé Bottino, V. 2001. Memorie di un Borghese del Novecento. L'Avventura di un Pioniere dell'Industria, ed. Laura Lepri. Milano: Bompiani.

Canova, C.M. 1933. Il Grattacielo dei Bimbi FIAT in 100 Giorni. Il Bianco e il Rosso, II, 5 (July 1933-XI): 2-3.

Ciucci, G. 1989. Gli Architetti e il Fascismo. Architettura e Città 1922-1944. Torino: Einaudi.

Ciuffetti, A. 2004. Casa e Lavoro. Dal Paternalismo Aziendale alle "Comunità Globali”: Villaggi e Quartieri Operai in Italia tra Ottocento e Novecento. Narni: Giada.

Conti, G. 2010. Modelli Geometrici per 1'Architettura: Spirali, Eliche ed Elicoidi. In: Il Modello in Architettura: Cultura Scientifica e Rappresentazione, eds. Emma Mandelli and Uliva Velo, 93-102. Florence: Alinea.

Cresti, C. 1986. Architettura e Fascismo. Florence: Vallecchi.

Cresti, C., B. Gravagnuolo and F. Gurrieri. 2004. Architettura e Città negli Anni del Fascismo in Italia e nelle Colonie. Firenze: Angelo Pontecorboli Editore. 
Cutini, V. and R. Pierini. 1993. Le Colonia Marine della Toscana. La Conoscenza, la Valorizzazione, il Recupero dell'Architettura per la Riqualificazione del Territorio. Pisa: Edizioni ETS.

Danesi S. and L. Patetta (eds.). 1988. Il Razionalismo e l'Architettura in Italia Durante il Fascismo. Milano: Electa.

De Seta, C. 1988. Cultura e Architettura in Italia tra le Due Guerre: Continuità e Discontinuità. In: Il Razionalismo e l'Architettura in Italia Durante il Fascismo, eds. Silvia Danesi and Luciano Patetta, 7-12. Milano: Electa.

De Seta, C. 2008. Giuseppe Pagano. Architettura e Città Durante il Fascismo. Milano: Jaka Book.

Gruppo 7. 1926. Architettura I. La Rassegna Italiana (December 1926).

Lamberti, C. 2003. Il Movimento Futurista e la Città. Urbanistica: Rivista dell'Istituto Nazionale di Urbanistica, 121 (August): 98-104.

Marinetti, F. T. 1914. Lo Splendore Geometrico e Meccanico e la Sensibilità Numerica. Milano: Direzione del Movimento Futurista.

Nicoloso, P. 2011. Mussolini Architetto. Propaganda e Paesaggio Urbano nell'Italia Fascista. Torino: Einaudi.

Sala, N. and G. Cappellato. 2003. Viaggio Matematico nell'Arte e nell'Architettura. Milano: Franco Angeli Ed.

Sant'Elia, A. 1914. L'Architettura Futurista. Manifesto. Milano: Direzione del Movimento Futurista.

Tofanelli, A. (ed.). 1932. Le Opere del Fascismo. Milano: Istituto Editoriale Nazionale.

Vivaldi, G. 2006-2007. L'ex Colonia FIAT 'Edoardo Agnelli' a Marina di Massa. Bachelor Thesis, University of Florence.

Zevi, B. 1973. Il Linguaggio Moderno dell'Architettura. Torino: Einaudi.

Marco Giorgio Bevilacqua engineer Ph.D., is Assistant Professor of Architectural Representation at the University of Pisa. His research interests are in the field of valorization of historical architectural heritage, with particular attention to historical military architecture, architectural and urban surveys and digital technologies for the communication of historical architectural heritage. He has presented conferences and lectures and published several works and papers on his main research topics, including, for the Nexus Network Journal: 'The Conception of Ramparts in the Sixteenth Century: Architecture, 'Mathematics' and Urban Design" [NNJ, 9, 2 (2007), pp. 249-261], "The Turkish Baths in Elbasan: Architecture, Geometry and Wellbeing', with Roberto Castiglia [NNJ, 10, 2 (2008), pp. 307-321] and "Alexander Klein and the Existenzminimum: A 'Scientific' Approach to Design Techniques"' [NNJ, 13, 2 (2011), pp. 297-313]. He is co-author with Kim Williams of "Leon Battista Alberti's Bombard Problem in Ludi matematici: Geometry and Warfare', [The Mathematical Intelligencer, 34, 8 (2013), pp. 27-38], and "Alberti and Military Architecture in Transition" [NNJ 16, 3 (2014), pp. 523-541]. 